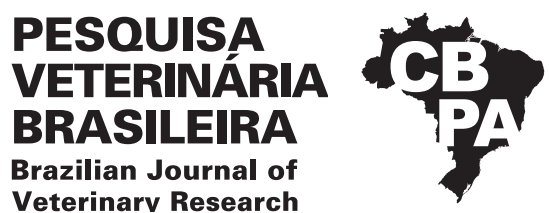

\title{
Livestock rabies in Pará state, Brazil: a descriptive study (2004 to $2013^{1}$ )
}

\author{
Elane A. Andrade ${ }^{2}$ (D), Francisco D.O. Monteiro ${ }^{3}$, Mónica R. Solorio², \\ Vanessa A. Raia ${ }^{4}$, Diego A. Xavier ${ }^{7}$ (D) Elvira Colino ${ }^{5}$, \\ Ricardo J.P.S. Guimarães ${ }^{6}$ (D) and Isis $\mathrm{Abel}^{2 *}$ (D)
}

\begin{abstract}
Andrade E.A., Monteiro F.D.O., Solorio M.R., Raia V.A., Xavier D.A., Colino E., Guimarães R.J.P.S. \& Abel I. 2020. Livestock rabies in Pará state, Brazil: a descriptive study (2004 to 2013). Pesquisa Veterinária Brasileira 40(4):234-241. Laboratório de Epidemiologia e Geoprocessamento, Instituto de Medicina Veterinária, Universidade Federal do Pará, Campus Castanhal, BR-316 Km 61, Saudade II, Castanhal, PA 68740-970, Brazil. E-mail: isisabel@ufpa.br

Rabies is an important zoonosis to public health associated with lethal encephalitis and economic losses. Analysis of its spatial distribution is a meaningful tool in understanding its dispersion, which may contribute to the control and prophylaxis of the disease. This study analyzed the spatial-temporal distribution of rabies outbreaks in livestock in Pará state, Brazil, from 2004 to 2013. We used records of neurological syndromes obtained from the state's livestock authority (Adepará). The analysis recorded 711 neurological syndromes reports in livestock, of which $32.8 \%$ were positive for rabies. In $8 \%$ of the neurological syndromes $(n=57)$ was not possible to perform the analysis because of bad-packaging conditions of the samples sent. Outbreaks involved at least 1,179 animals and cattle were the most affected animal species $(76.8 \%)$. The numbers of reported neurological syndromes and of rabies outbreak shad strong positive correlation and exhibited decreasing linear trend. Spatially, most outbreaks occurred in two mesoregions in Pará (Northeast and Southeast). One of the justifications for this spatial distribution may be related with the distribution of the animals in the state, since these mesoregions are the largest cattle producers in Pará and have most of their territory deforested for pasture implementation.
\end{abstract}

INDEX TERMS: Rabies, surveillance, livestock, Eastern Amazon, Pará, Brazil, cattle.

RESUMO.- [Raiva em herbívoros no estado do Pará, Brasil: estudo descritivo (2004 a 2013).] A raiva é uma zoonose importante para a saúde pública associada à encefalite letal e às perdas econômicas. A análise de sua distribuição espacial é uma ferramenta importante no entendimento de sua dispersão, o que pode contribuir para o controle e a profilaxia da doença. Este estudo analisou a distribuição espaço-temporal do surto de raiva em rebanhos no estado do Pará, Brasil, entre 2004 e

\footnotetext{
${ }^{1}$ Received on April 27, 2019.

Accepted for publication on May 8, 2019.

${ }^{2}$ Laboratório de Epidemiologia e Geoprocessamento (EpiGeo), Instituto de Medicina Veterinária (IMV) Universidade Federal do Pará (UFPA), BR-316 Km 31, Castanhal, PA 69746-360,Brazil.E-mails: elane.saraiva@hotmail.com, monicasolorio@gmail.com *Corresponding author: isisabel@ufpa.br

${ }^{3}$ Instituto Federal de Educação do Tocantins (IFTO), Quadra Ae 310 Sul, Av. NS 10, 0, Plano Diretor Sul, Palmas, TO 77021-090, Brazil. E-mail: deciomonteiro@ifto.edu.br
}

2013. Foram utilizados registros de síndromes neurológicas obtidas junto à agência de defesa agropecuária do estado (Adepará). A análise revelou 711 notificações de síndromes neurológicas em herbívoros, das quais $32,8 \%$ foram positivas para raiva. Em $8 \%$ das síndromes neurológicas $(n=57)$ não foi possível realizar as análises devido às más condições das amostras enviadas. Surtos envolveram pelo menos 1.179 animais e os bovinos foram a espécie animal mais afetada

\footnotetext{
${ }^{4}$ Graduate Program in Health Sciences (PPGCS), Universidade Federal de Mato Grosso (UFMT), Av. Alexandre Ferronato 1200, Res. Cidade Jardim, Sinop, MT 78698-000, Brazil. E-mail: vanessaraiaufrrj@gmail.com

${ }^{5}$ Agência de Defesa Agropecuária do Pará (Adepará), Av. Pedro Miranda 1666, Pedreira, Belém, PA 66085-023, Brazil. E-mail: elvira.colino@gmail.com

${ }^{6}$ Laboratório de Geoprocessamento, Instituto Evandro Chagas, Rodovia BR-316 Km 7, Levilândia, Ananindeua, PA 67030-000, Brazil. E-mail: ricardojpsg@gmail.com

${ }^{7}$ Programa de Capacitação Institucional, Coordenação Ciências da Terra e Ecologia, Museu Paraense Emílio Goeldi, Campus de Pesquisa, Av. Perimetral 1901, Terra Firme, Belém, PA 66077-830,Brazil. E-mail: diego.a.xavier@gmail.com
} 
(76,8\%). Os números de síndromes neurológicas relatadas e de surtos de raiva apresentam forte correlação positiva e exibem tendência linear decrescente. Espacialmente, a maioria dos surtos ocorreu em duas mesorregiões no Pará (Nordeste e Sudeste). Uma das justificativas para essa distribuição espacial pode estar relacionada à distribuição dos animais no estado, uma vez que essas mesorregiões são os maiores produtores de gado do Pará e possuem grande parte do seu território desflorestado para implantação de pastagens.

TERMOS DE INDEXAÇ̃̃O: Raiva, vigilância, herbívoros, Amazônia Oriental, Pará, Brasil, bovinos.

\section{INTRODUCTION}

Rabies virus (RabV) belongs to the genus Lyssavirus, family Rhabdoviridae, and affects the central nervous system (CNS), causing fatal encephalitis. In majority countries, the rabies virus reservoirs are domestic and wild carnivores, although some Chiroptera species and other mammal species may also host the pathogen (Mollentze et al. 2014). The hematophagous bat species, Desmodus rotundus, is known to transmit rabies to livestock in Latin America, causing economic losses in the continent (Schneider et al. 2009). The abundance of D. rotundus in Brazil has been associated with deforestation and increase of bovine density. Deforestation reduces the availability of natural preys, increasing the chances of contact of RabV with humans. Although, there are few reports about RabV transmission to humans by handling of farm animals, these assume greater importance in the surveillance of viral circulation, being considered sentinels of disease outbreaks, alerting the circulation of the virus in a particular region (Wada et al. 2011).

Covering an area of approximately $1,248,000 \mathrm{~km}^{2}$ in the Amazon region, the Pará state, Brazil, has 144 municipalities distributed in 22 micro-regions and six mesoregions (IBGE 2015). The state has 21 million of farmed animals bred in the state and a diversified landscape that includes environmental protection areas, indigenous peoples' reserves, pastures, and agricultural zones that many times are all adjacent to forest fragments. From 1999 to 2004, rabies cases in livestock in the state occurred mainly in the mesoregion Southeastern Pará (Fernandes et al. 2013). According to Braga et al. (2014), mesoregions Northeastern and Southeastern Pará were considered areas of intermediate to high risk for rabies, where the landscape is favorable to the survival of the D. rotundus, since almost all municipalities are considered as receptive to the bat. Other environmental conditions, as proximity to highways and rivers, were cited as important in this scenario (Andrade et al. 2016). However, a study with more details, taking in consideration regional peculiarities is necessary to comprehend this distribution and to be an important tool to establish control strategies.

In Pará state, few studies about this topic were realized. A descriptive, temporal, and spatial investigation more detailed would prove its importance in the effort towards understanding rabies occurrence, making clear the reality of this disease in the region. Therefore, the present study aims to describe the spatial and temporal patterns of rabies distribution from 2004 to 2013 in livestock in Pará state, Brazil.

\section{MATERIALS AND METHODS}

This study used data obtained by the "Agência de Defesa Agropecuária do Estado do Pará" (Adepará) in two forms: Early Disease Investigation Report (FORM-IN) and Complementary Disease Investigation Report (FORM-COM). Adepará uses this report to record neurological syndromes in farmed animals and this study used reports registered from January 1, 2004, to December 31, 2013. The following variables were used: year, month, and municipality where outbreaks occurred, purpose of farming (dairy, beef or mixed), agent reporting of suspected case, affected species, productive system (technified or not) and farming activity. The analyses considered only the accuracy of the data provided, that is, unclearly stated information and boxes left blank in forms were not considered.

After every notification of a suspected neurological disease, Adepará agents collected fragments of the CNS of animals, including portions of the frontal cortex, cerebellum, and brainstem. Furthermore, according to recommendations of the "Ministério da Agricultura, Pecuária e Abastecimento" (MAPA), fragments of the spinal cord of equids were also collected (Brasil 2009). All material was kept under refrigeration for posterior analysis in the "Laboratório Nacional Agropecuário" (Lanagro/PA) from MAPA, in Belém, the capital city of Pará state. Diagnosis was conducted using direct immunofluorescence (DIF) and intracerebral inoculation of mice (IIM). According to Lanagro's diagnosis, cases were classified in three categories: inappropriate sample, positive for rabies or negative for rabies. Inappropriate samples were considered those in putrefaction stage, when received by Lanagro. According to Portaria no 168/2005 from Animal Health Department (SDA), a notified neurological condition case is considered as rabies outbreak when at least one sample was positive during the tests realized.

A databank was created with Adepará's data in Microsoft Excel software to perform the linear regression analysis and temporal trends of the reports and of the rabies outbreaks. After that, Pearson's correlation coefficient $(\rho)$ was calculated considering $\mathrm{p} \leq 0.05$ as significant. Subsequently, these data were exported to the software SPSS v.20.0, to realize a descriptive statistical analysis of the variables selected. The Chi-square test was applied for that, if necessary, the odds ratio would be calculated. A 95\% confidence interval was considered significant.

Mapping and spatial analysis were conducted in ArcGis 10.3, using a Geographical Databank and the Chart Encyclopedia published by the "Instituto Brasileiro de Geografia e Estatística" (IBGE). The layers representing municipality, hydrography, animal density, indigenous areas, sustainable use areas and integral conservation areas were superimposed on the distribution map of rabies outbreaks.

\section{RESULTS}

During the study period 711 notifications of neurological syndromes were recorded in 101 municipalities of Pará state. Of total, 233 reports (32.8\%) were positive to rabies and for $8 \%$ of the notifications, the final diagnosis was inconclusive. Only 633 reports were completely filled and 684 reports contained information about the origin of notification (defense agency). Positive cases were reported by farmers, private veterinarians and Adepará (28.4\%, 29.8\% and 56.7\%, respectively) (Table 1 ).

In total, 730 samples were collected, once in some properties fragments were collected in more than one animal, as recommended by Portaria no 168/2015. So, rabies outbreaks affected at least 1,179 animals. Moreover, $65 \%$ of 
the rabies outbreaks occurred in animals that integrate the main activity of the farm. Regarding productive system, 78,6\% of properties showed non-technified and $57 \%$ recorded beef cattle, followed by mixed production animals (33.3\%), and dairy cattle $(7.8 \%)$. The results obtained did not reveal any correlation between the variables associated with farming activity and the results of rabies tests $(p>0.05)$.

The majority positive rabies cases were registered in cattle $(182,76.8 \%)$, followed by equids $(44,18.6 \%)$, bubalines $(5$, $2.1 \%)$, and pigs $(4,1.7 \%)$. Goats and sheep accounted one positive case each $(0.4 \%)$.

During the study period, the number of reported neurological syndromes in livestock showed a declining trend, with fewer 5.01 cases notified per year. In the same way, the positive cases for rabies decreased in 2.6 cases per year, showing a strong positive correlation between these two variables $(\rho=0.81$ ) (Fig.1). Furthermore, rabies cases occurred mainly in March and July, $16.0 \%$ and $13.5 \%$, respectively, showing no seasonal trend.

The spatial analysis showed that rabies outbreaks incidence during the studied period were distributed in 59 of the 101 municipalities wherein a neurological syndrome was reported, and $52.4 \%$ of rabies outbreaks were concentrated in nine municipalities, mainly in Northeast and Southeast mesoregions. However, the municipalities with the most animal density did not show the highest incidence for rabies (Fig.2).

Table1. Source of notification from fully filled reports

\begin{tabular}{lccc}
\hline \multicolumn{1}{c}{ All notifications (711) } & $\mathrm{n}$ & $\%$ & Positive (\%) \\
\hline Completely filled & 633 & 89 & - \\
Origin of the notification & 684 & 96.2 & - \\
$\quad$ Farmers & 457 & 70.5 & 28.4 \\
Private veterinarians & 124 & 19.3 & 29.8 \\
Agents of Adepará & 67 & 10.2 & 56.7
\end{tabular}

The outbreaks were distributed along the main roads and/or evident deforestation areas, as observed for Transamazonian Highway and in Northeast mesoregion of state (Fig.3). There were no cases in Marajó mesoregion. Furthermore, other silent regions were recognized as indigenous territory or as conservation areas, although cases were registered surrounding these localities (Fig.4).

\section{DISCUSSION}

The present study applied spatial and temporal trend analysis to comprehend livestock rabies distribution during 10 years of surveillance observation in Pará state in Amazon region.

In general, the notification of outbreaks registered was done principally by the farm owners, corroborating with the study developed in Paraíba state, Brazil (Andrade et al. 2014). According to results, Pará's surveillance strategy for livestock was characterized as predominantly passive. The higher number of reports done by farmers may be related to the fact that two human's rabies outbreaks were recorded in 2004 and 2005, registering 39 died people by hematophagous bats aggression. Of these deaths, 22 occurred in 2004, in Portel municipality (Marajó mesoregion) and Viseu municipality (Northeast mesoregion). The others 17 deaths were recorded in 2005, in Augusto Corrêa municipality (Northeast mesoregion) (Brasil 2004,2015 ). Possibly, the news of rabies cases in the state broadcast by the media promoted awareness and, in turn, influenced the numbers of reports by farmers, registering the highest numbers from 2005 to 2008, with $59.7 \%$ of the cases notified during the whole study period. This result demonstrated the important role of awareness campaigns to maintain the adequate level of watchfulness across farmers.

All CNS samples of rabies suspected animals in the period considered in the present study $(\mathrm{n}=730)$ were analyzed. In some farms, CNS samples were collected from more than

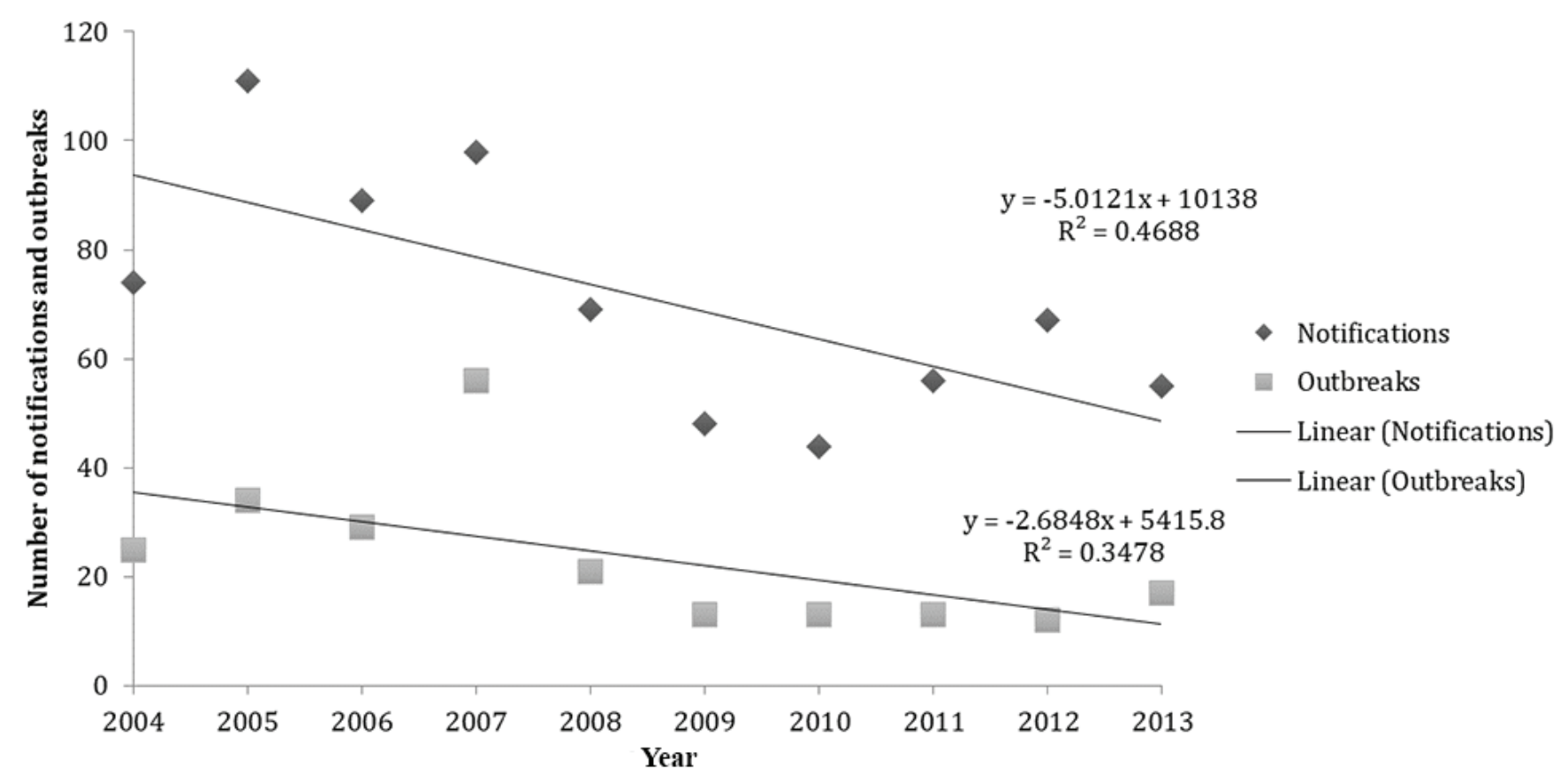

Fig.1. Distribution of notified cases of neurological syndromes in livestock in the state of Pará, Brazil, and rabies outbreaks from 2004 to 2013. 
one animal. Of this number, $8 \%(n=57)$ were considered inappropriate for analysis. Possibly, some logistic problems as transportation of refrigerated samples, farms localization and transportation duration could be related with this problem. Importantly, in addition to problems in highway infrastructure, the extensive territorial size and the diverse rivers that flow across the state are obstacles for maintaining the appropriate condition of a sample. In some cases, the samples collected were more than $800 \mathrm{~km}$ of distance from Belém, where the analyses were realized. More than $50 \%$ of these inappropriately preserved samples were transported by barges (which is a rather slow transportation), moreover,
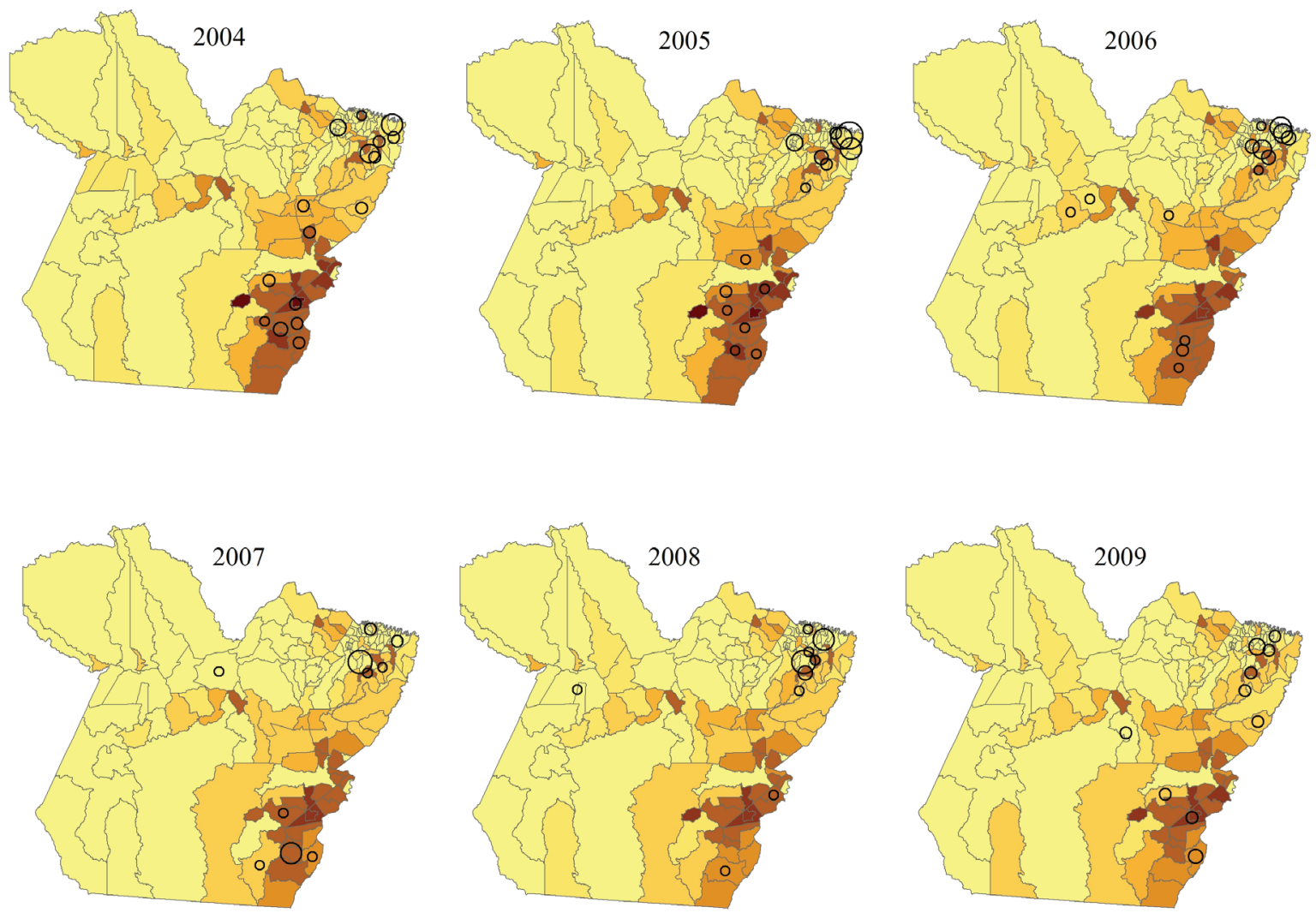

Incidence

(per 10000 animals)
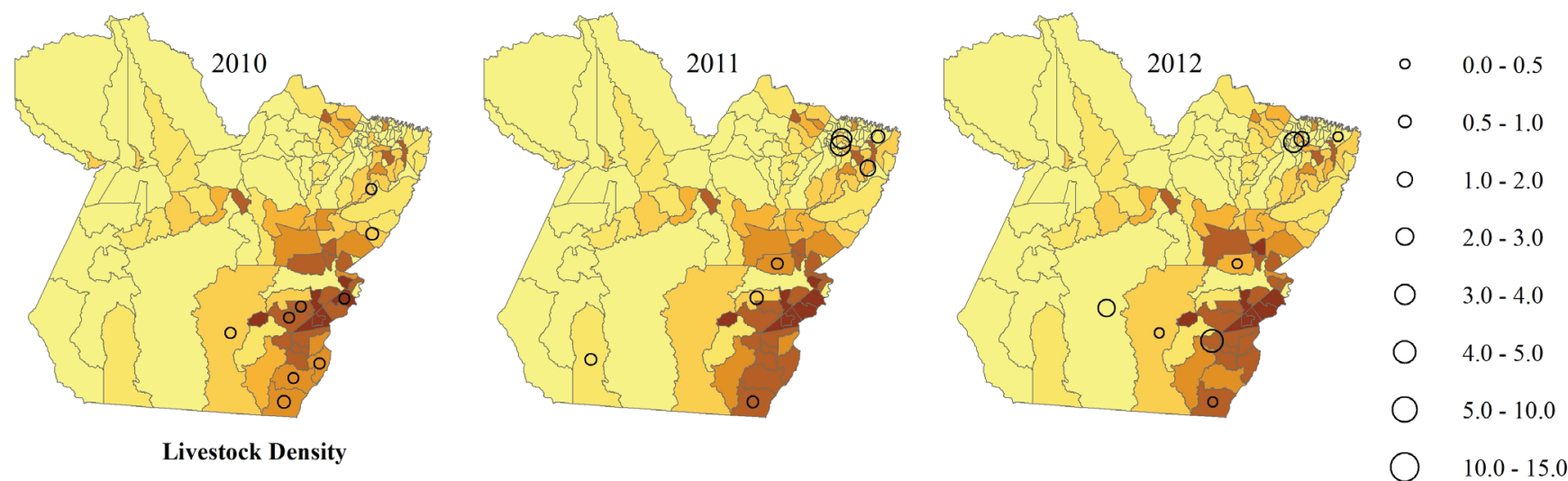

Livestock Density

$0.0-15.0$

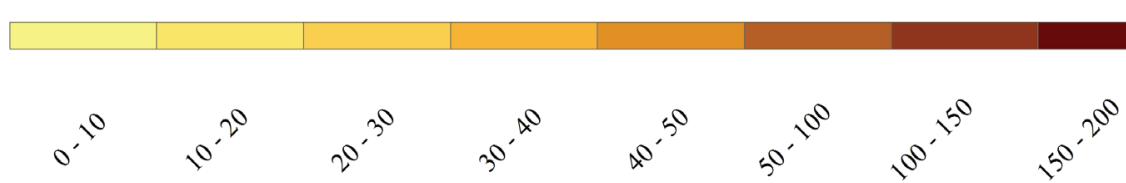

Fig.2. Annual maps of the incidence of rabies cases (cases per 10,000) and average density of livestock animals according to municipalities in the state of Pará from 2004 to 2012. 
the climatic conditions of the region can also contribute to samples deterioration. In this way, histopathological and immunohistochemical methods should be considered as complementary techniques to detect rabies in large regions like Pará state. These methods present good correlation with DIF findings, and may improve the possibility of preserving biological samples for RabV analysis. These methods may be conserved in formalin, by passing the logistic difficulties discussed (Abreu et al. 2012).

Once rabies outbreaks were confirmed, our attention should be directed to the role of these animals in farm activity. In $65 \%$ of the rabies outbreaks, the animals of the main activity in the given farm were more affected. It leads to a reflection about economic impacts of losing these animals to the disease, in specifically for small farms, since $78.6 \%$ of the outbreaks identified during the studied period were rural properties without technician production systems in place, adopting extensive cattle farming techniques.

Although we did not detect any association between rabies results and the variables describing production systems (farming activity, technification of farming, purpose of farming) ( $p>0.05$ ), the way cattle farming has been conducted in Pará state in the last decades showed suitable conditions for reproduction of hematophagous bat populations in these farms. This may be explained because of livestock farming takes place in areas that vary in terms of receptivity, and are surrounded by permanent forest fragments (Braga et al. 2014).

The pattern of distribution of rabies cases observed, considering the species affected by the disease, was described in other regions of the country (Wada et al. 2011, Lopes et al. 2015). The main nourishment source for Desmodus rotundus, especially, is the pig's blood (Bobrowiec et al. 2015). However, pig farming is not a significant economic activity in Pará state, explaining the low percent number of samples positive for rabies from these farmed animals.

Although cattle breeding is the main activity in Pará state, presenting areas with high bovine density, Braga et al. (2014) showed that there is not association between bovine density and hematophagous bat distribution. In the same way, authors believe that there are not associations between bovine density and rabies cases that occurred in these animals. Andrade et al. (2016) showed analysis that oppose those data, observing that high-risk areas for bovine rabies were related to large herds cattle in Pará state. Nevertheless, in an observation of ten years, this study showed no evidences that rabies cases occur where there is a high livestock density. It seems that bats prefer cattle blood even when wild animals are present in the same environment, possibly because cattle become easy prey due to confinement restrictions (Voigt \& Kelm 2006).

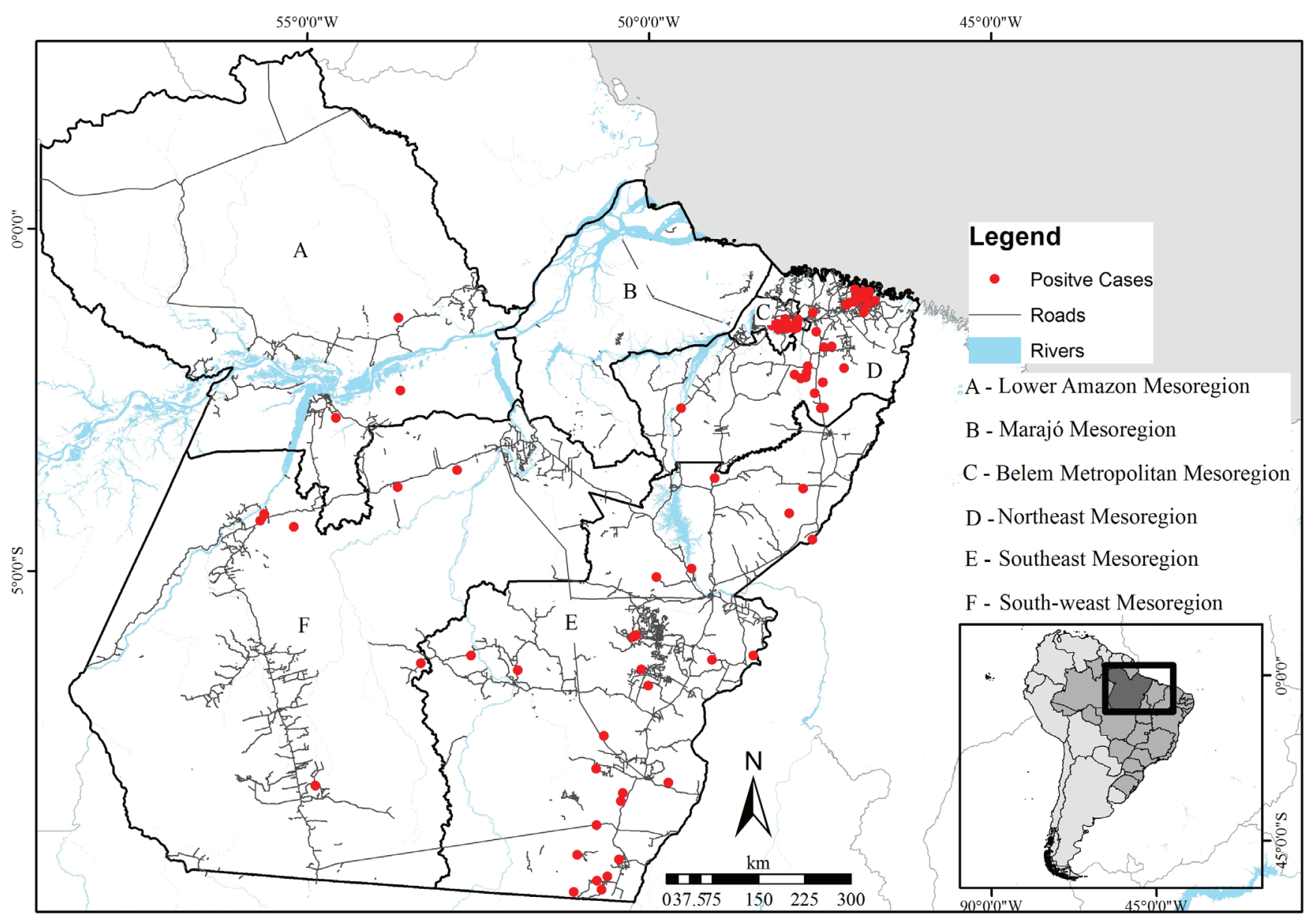

Fig.3. Livestock rabies cases, rivers and roads distribution in the state of Pará from 2004 to 2013. 
Equids were the second species affected by rabies during the investigation period, showing $18.6 \%$ of cases $(44 / 237)$, corroborant with other studies carried out in the region (Casseb et al. 2006, Póvoas et al. 2012). However, proximity 50\% of the notified cases of neurological syndromes in equids were positive for rabies (47\%). Compared with equids, the most preventive measures are directed to cattle due to the greater economic importance of bovine herds. The data obtained in this study point to the need for more attention to equids in rabies surveillance programs.

In Brazil, $50 \%$ of the bubaline herds are reared in Pará state. Despite that, just $2.9 \%$ of notified rabies cases affected this species. It is believed that the physiological and behavioral traits of buffaloes, besides the use of extensive farming methods in farms with no fences, especially in the Marajó mesoregion, difficult that the bats feed on these herds and the geographic features of the Marajó island also difficult the Adepará to inspect these animals.

Most rabies outbreaks were reported in mesoregions Northeastern and Southeastern Pará, with some cases registered in Southwestern Pará, classifying these areas as posing intermediate to high risk for rabies (Braga et al. 2014). Andrade et al. (2016) showed that rabies cases in bovines, especially in Pará may be associated with the expansion of cattle farming in the state, reflecting in the increment of deforestation areas. These areas have been deforested in the last decades with highly anthropic actions and they are included in the Eastern Amazon Arc of deforestation (Domingues \& Bermann 2012).

Marajó mesoregion was characterized as a silent area. This region does not present roads to provide access to farms where rabies cases may occur. Other geographical characteristics is the presence of large rivers, acting as barriers to surveillance and playing an important role in rabies transmission (Mungrue \& Mahabir 2011). Possibly, the absence of positive cases may be related with the difficulties in transport, reflecting in register of notifications. The possibility of rabies occur in these areas in a silent way may not be discharged, once animals are bred extensively without limits between properties, offering favorable conditions to bat attacks.

Conservation areas or indigenous reserves are, possibly, other silent areas observed in this study. These areas are located along the borders with the neighboring Amazonas, Amapá and Mato Grosso states and were classified as low risk areas for human and bovine rabies by Andrade et al. (2016). The surveillance actions are limited in these areas, especially in indigenous areas, that are under the jurisdiction of Brazilian governmental protection agency for Indian interests and their culture, the "Fundação Nacional do Índio" (FUNAI). This agency is the responsible to authorize the entry of surveillance

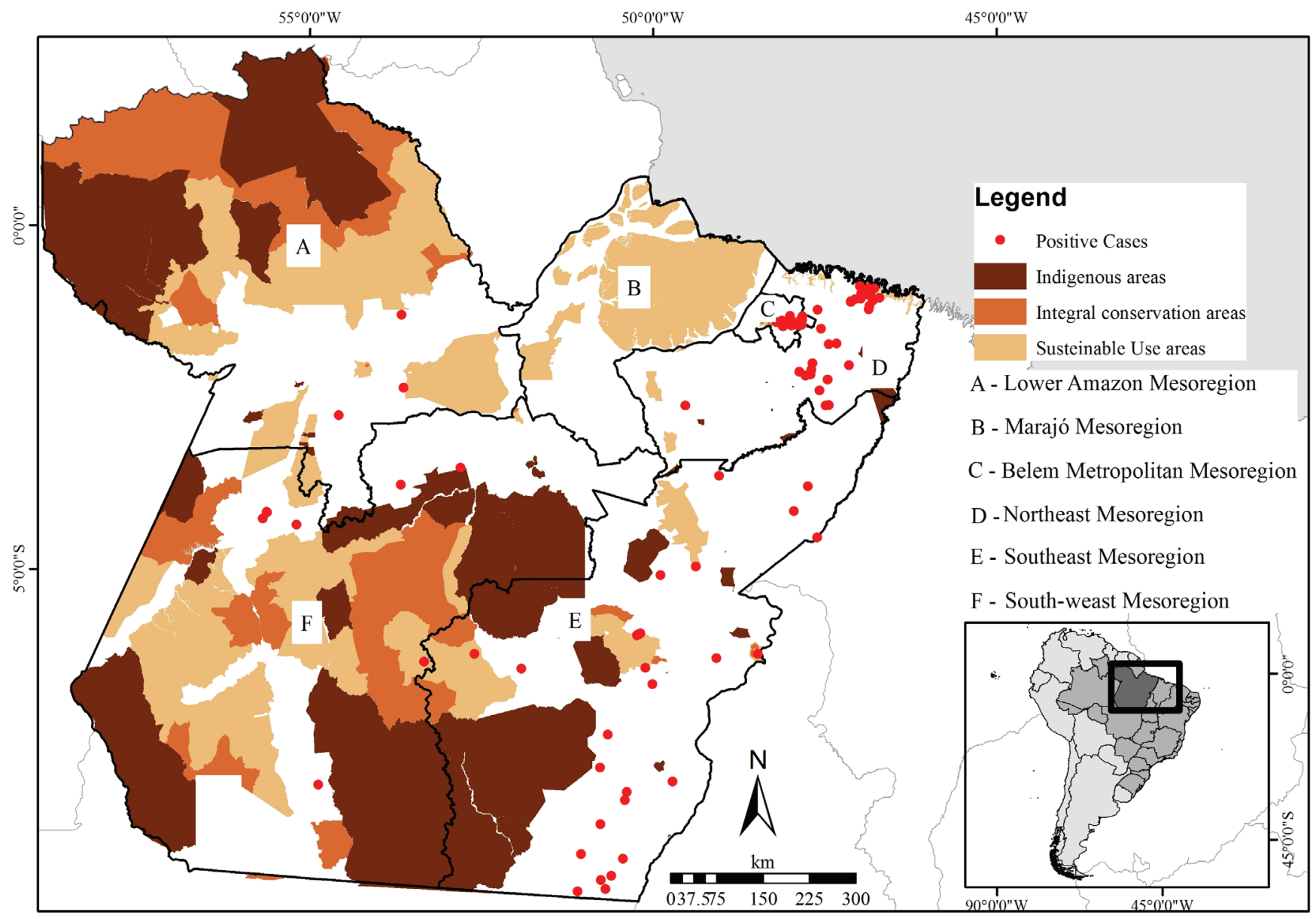

Fig.4. Livestock rabies cases and conservations areas in the state of Pará from 2004 to 2013. 
services. Rabies cases were observed in deforested areas next to indigenous and conservation reserves, probably, because lose shelter and primarily food source. In this scenario, the conservation and indigenous areas show favorable conditions for installation of bats (Dias et al. 2011). This may explain areas with sporadic rabies cases in this study, although without description in forest areas (Mungrue \& Mahabir 2011).

The positive correlation between notified cases and outbreaks indicates the importance of report in the identification of cases. Furthermore, the data demonstrate that cases follow a decreasing trend. However, in fact, notifications are decreasing in the studied period. Added for this, probably the sanctioning of the 'Technical Guide for the Control of Rabies in Herbivores' in 2005 may also have influenced in these results, affording to adopt standardized measures to control the disease in Brazil (Lopes et al. 2015). The present investigation revealed that the most cases were notified by breeders and veterinarians. Therefore, sanitary education initiatives should be directed for these people, searching to improve surveillance measures.

The data analyzed showed that most rabies cases were reported in March and June. Pará state is located in Eastern Amazon and its location experiment a complex climate influenced by the large rivers and the heterogeneous vegetation. The pluviometric indices varies from 1000 to $4500 \mathrm{~mm}$ along the region. The state registers two season: the rainy season, known as amazon winter (from December to June) and the less rainy season, called amazon summer (from July to November). In this study, seasonality and rabies incidence in cattle did not show correlation. However, some researchers suggest that depending on the climate conditions bats change roosting sites and reorganize their colonies, explaining rabies outbreaks during the cold, rainy seasons (Gomes et al. 2011).

The results obtained may explain that even under adverse conditions, the bats exhibit a considerable adaptation skill for both natural and artificial shelters, especially in the Amazon region, where there is a wide variety of natural habitats, providing shelter during all year round. This casts doubts as to the actual relationship between seasonality and bat migration habits (Gomes \& Uieda 2004). In fact, more studies are necessary to shed more light on these aspects, especially the population dynamic of D. rotundus in Pará and its relationship with rabies outbreaks in livestock at given times during the year, considering regional peculiarities.

\section{CONCLUSIONS}

The present study confirmed that rabies is endemic and does not present seasonality in Pará state, showing how Northeastern and Southeastern mesoregions stand out with the highest rabies cases in the region. However, the municipalities with higher animal density did not show the highest rabies incidence. Furthermore, the spatial dynamics of the disease accompanies areas where there are more roads.

The roads absence associated with the presence of large rivers may difficult surveillance in the more distant properties.

An important fact is the need for improved surveillance measures against rabies in equines.

Although, the parameters analyzed and positive rabies cases did not show any association, it was possible to observe that other diagnosis tools are required to consider regional peculiarities in rabies dynamic. Similarly, educational initiatives to explain the role of livestock owners in the reporting of neurological diseases in livestock should be implemented as part of a wider surveillance strategy in Pará state, in the Brazilian Amazon.

Acknowledgements.- The authors thank PARC/PROPESP and PAPQ/ PROPESP for financial support; the "Agência de Defesa Agropecuária do Estado do Pará" (Adepará) for sharing the database; and the researchers V.D. Cerqueira and C.C.G. Moraes for the valuable contributions.

Conflict of interest statement.- The authors declare that there are no conflicts of interest of a financial or personal nature

\section{REFERENCES}

Abreu C.C., Nakayama P.A., Nogueira C.I., Mesquita L.P., Lopes P.F.R., Varaschin M.S., Ferreira E. \& Bezerra Jr P.S. 2012. Domestic microwave processing for rapid immunohistochemical diagnosis of bovine rabies. Histol. Histopathol. 27(9):1227-1230.<http://dx.doi.org/10.14670/HH-27.1227> <PMid:22806910>

Andrade F.A., Gomes M.N., Uieda W., Begot A.L., Ramos O.S. \& Fernandes M.E.B. 2016. Geographical analysis for detecting high-risk areas for bovine/human rabies transmitted by the common hematophagous bat in the Amazon Region, Brazil. PLoS One 11(7):e0157332. <http://dx.doi.org/10.1371/ journal.pone.0157332><PMid:27388498>

Andrade J.S.L., Azevedo S.S. Peconick A.P., Pereira S.M., Barçante J.M.P., Vilar A.L.T. \& Silva M.L.C.R. 2014. Estudo retrospectivo da raiva no Estado da Paraíba, Brasil, 2004 a 2011. Braz. J. Vet. Res. Anim. Sci. 51(3):212-219. <http://dx.doi.org/10.11606/issn.1678-4456.v51i3p212-219>

Bobrowiec P.E.D., Lemes M.R. \& Gribel R. 2015. Prey preference of the common vampire bat (Desmodus rotundus, Chiroptera) using molecular analysis. J. Mammalog. 96(1):54-63. <http://dx.doi.org/10.1093/jmammal/gyu002>

Braga G.B., Grisi-Filho J.H.H., Leite B.M., Sena E.F. \& Dias R.A. 2014. Predictive qualitative risk model of bovine rabies occurrence in Brazil. Prev. Vet. Med. 113(4):536-546. <http://dx.doi.org/10.1016/j.prevetmed.2013.12.011> <PMid:24433635>

Brasil 2004. SVS: surto de raiva humana transmitida por morcegos no município de Portel, Pará. Boletim eletrônico epidemiológico, Secretaria de Vigilância em Saúde, Ministério da Saúde, Brasília, DF.

Brasil 2009. Controle da raiva dos herbívoros. Manual técnico 2009, Secretaria de Defesa Agropecuária, Ministério da Agricultura, Pecuária e Abastecimento (MAPA), Brasília, DF

Brasil 2015. Casos de raiva humana, Grandes regiões e Unidades Federadas 1990 a 2015. Serviço de Vigilância em Saúde, Ministério da Saúde, Brasília, DF.

Casseb L.M.N.S., Barbosa T.F., Pereira A.S., Vieira C.A., Medeiros D.B.A., Vasconcelos P.F.C., Travassos da Rosa E.S. \& Casseb A.R. 2006. Prevalência de raiva animal em amostras procedentes da região norte do Brasil, diagnosticadas no Instituto Evandro Chagas no Período de 2000 a 2004. Revta Ciênc. Agrárias 46:261-274.

Dias R.A., Nogueira-Filho V.S, Goulart C.S., Telles I.C.O., Marques G.H.F., Ferreira F., Amaku M. \& Ferreira-Neto J.S. 2011. Modelo de risco para circulação do vírus da raiva em herbívoros no estado de São Paulo, Brasil. Revta Panam. Salud Publ. 30(4):370-376.

Domingues M.S. \& Bermann C.0. 2012. Arco de desflorestamento na Amazônia: da pecuária a soja. Ambient. Soc., São Paulo, 15(2):1-22. <http://dx.doi. org/10.1590/S1414-753X2012000200002>

Fernandes M.E.B., Costa L.J.C., Andrade F.A.G. \& Silva L.P. 2013. Rabies in humans and non-human in the state of Pará, Brazilian Amazon. Braz. J. Infect. Dis. 17:251-253.<http://dx.doi.org/10.1016/j.bjid.2012.10.015>

Gomes M.N. \& Uieda W. 2004. Abrigos diurnos, composição de colônias, dimorfismo sexual e reprodução do morcego hematófago Desmodus rotundus (E. Geoffroy) (Chiroptera, Phyllostomidae) no Estado de São 
Paulo, Brasil. Revta Bras. Zool. 21(3):629-638.<http://dx.doi.org/10.1590/ S0101-81752004000300025>

Gomes M.N., Monteiro A.M.V. \& Escada M.I.S. 2011. Raiva bovina segundo os mosaicos de uso e cobertura da terra no estado de São Paulo entre 1992 e 2003. Arq. Bras. Med. Vet. Zootec. 63(2):287-295. <http://dx.doi. org/10.1590/S0102-09352011000200003>

IBGE 2015. Pesquisa Pecuária Municipal (PMM), Sistema IBGE de Recuperação Automática (SIDRA), Instituto Brasileiro de Geografia e Estatística.

Lopes E., Sáfadi T., Rocha C.M.B. \& Cardoso D. L. 2015. Analysis of time series of cattle rabies cases in Minas Gerais, Brazil, 2006-2013. Trop. Anim. Health Prod. 47(4):663-670. <http://dx.doi.org/10.1007/s11250-015-0775-x> $<$ PMid:25698529>

Mollentze N., Biek R. \& Streicker D.G. 2014. The role of viral evolution in rabies host shifts and emergence. Curr. Opin. Virol. 8:68-72. <http://dx.doi. org/10.1016/j.coviro.2014.07.004> <PMid:25064563>

Mungrue K. \& Mahabir R. 2011. The rabies epidemic in Trinidad of 1923 to 1937: an evaluation with geographic information system. Wilderness
Environ. Med. 22(1):28-36.<http://dx.doi.org/10.1016/j.wem.2010.11.001> $<$ PMid:21377116>

Póvoas D.R., Chaves N.P., Bezerra D.C., Almeida V.M. \& Saraiva L.Q. 2012. Raiva em herbívoros no Estado do Maranhão: um estudo retrospectivo. Revta Bras. Ciênc. Vet. 19(2):86-89. <http://dx.doi.org/10.4322/rbcv.2014.083>

Schneider M.C., Romijn P.C., Uieda W., Tamayo H.M., Silva P.F., Belotto A., Silva J.B. \& Leanes L.F. 2009. Rabies transmitted by vampire bats to humans: an emerging zoonotic disease in Latin America? Revta Panam. Salud Publ. 25(3):260-269.<http://dx.doi.org/10.1590/s1020-49892009000300010> $<$ PMid:19454154>

Voigt A. \& Kelm D.H. 2006. Host preference of the common vampire bat (Desmodus rotundus, Chiroptera) assessed by stable isotopes. J. Mammalog. 87(1):1-6. <http://dx.doi.org/10.1644/05-MAMM-F-276R1.1>

Wada M.Y., Rocha S.M. \& Elkhoury A.N.M. 2011. Situação da raiva no Brasil, 2000-2009. Epidemiol. Serv. Saúde 20(4):509-518. <http://dx.doi. org/10.5123/S1679-49742011000400010> 